\title{
Phytochemicals from Beilschmiedia anacardioides and Their Biological Significance
}

\author{
Nkeng-Efouet-Alango Pépin \\ University of Dschang, \\ Cameroon
}

\section{Introduction}

Medicinal plants provide a vast array of raw materials for primary health care in Africa and other countries of the world. The World Health Organization (W.H.O) estimates that about $80 \%$ of Africans living in the continent have resort to traditional medical practitioners and the use of traditional medicine for the treatment of their diverse ailments. This practice has a considerable importance within the economic and cultural milieu of Africa.

It is estimated that less than $10 \%$ of the world's genetic resources have been studied seriously as sources of medicines. Yet from this small fraction, humanity has reaped enormous benefits.

The search for bioactive plant natural products from higher plants is gathering momentum, as they have potential to provide new lead compounds or to be of use directly. There is an increasing sense of urgency about this search due to the destruction of natural resources. With regards to these plants, it has been estimated that 25-30 million hectares of the world's rainforests are lost each year. The crucial problem already expressed by several scientists then is how to search efficiently and rapidly for bioactive components from the vast number of unstudied plants. Part of the solution is to narrow down the search-selection.

Six approaches to the selection of plant materials for study exist: the locally random, the taxonomic, the ethnobotanic, the phytochemical, the information based, and serendipity. The ethnomedical approach appears to be the method of choice for natural product chemists working in Africa and other developing countries. In this method only plants used in traditional medicine are collected.

Very little attention has been paid to Beilshmiedia species. Previous studies concern trees and herbs of Beilshmiedia species, with the aim of cultivating herbs containing the same endiandric acid derivatives as trees. Other studies led to a patent on interesting synthesis of endiandric acid derivatives.

In our own search for prospective pharmacological products from ethnobotanic data, we have been looking at some traditional medicines whose therapeutic efficiency is scientifically established towards biomedical analyses of patients on treatment in a specialized clinic. We have selected a traditional medicine based on one plant Beilshmiedia 
anacardioides (Lauraceae), for its proven efficiency on genital infections and rheumatisms through clinical research. No phytochemical studies of Beilshmiedia anacardioides are however to our knowledge available in the literature. We propose that phytochemists looking for novel bioactive natural products should investigate the medicinal plants whose therapeutic efficiency has been established through clinical research on African medicine.

The genus Beilschmiedia comprises about 200 species widely distributed in the intertropical region (Fouilloy, 1974). B. anacardioides stem bark is used in the Western Province of Cameroon to cure uterine tumours (Tchouala, 2001). Some other species of the genus Beilschmiedia are used in traditional medicine in Africa for the treatment of several ailments (Tchouala, 2001; Iwu, 1993). Previous phytochemical investigations of plants of the genus Beilschmiedia reported the presence of bio-active lignans (Chen et al., 2006; Chen et al., 2007), flavonoids (Harbone et al., 1969), triterpenoids (Chen et al., 2006); tetracyclic endiandric acid (Bandaranayake et al., 1981; Banfield et al., 1994) and alkaloids (Clezy et al., 1966; Kitagawa et al., 1993; Chouna et al., 2011).

We have initiated a systematic phytochemical investigation of the extracts of Beilshmiedia anacardioides as well as the antibacterial activity of the eight new compounds isolated, towards five strains of microbes, namely Bacillus subtilis, Micrococcus luteus, Streptococcus faecalis, Pseudomonas palida, and Escherichia coli.

The methods used for the isolation of the compounds were mainly column chromatography and preparative TLC. The structures of all compounds were elucidated by means of modern spectroscopic techniques such as 1D-NMR ( ${ }^{1} \mathrm{H}-\mathrm{NMR},{ }^{13} \mathrm{C}-\mathrm{NMR}$ with DEPT experiments), and 2D-NMR ( $\left.{ }^{1} \mathrm{H}-{ }^{1} \mathrm{H}-\mathrm{COSY}, \mathrm{HMQC}, \mathrm{HMBC}, \mathrm{NOESY}\right), \mathrm{MS}$, IR and X-Ray spectroscopies.

The antibacterial activities of the new compounds were examined using the dilution technique with respect to the zone of inhibition (ZI) and minimum inhibitory concentration (MIC).

We report here the results we have so far obtained and published in three renowned scientific journals (Chouna et al.,2009; 2010; 2011).

\section{Study of the ethnomedical preparation}

The ethnomedical preparation is a decoction.The decoction is prepared as follows: Boil about $80 \mathrm{~g}$ dry stem bark powder in 3 litres of water for 15 minutes. Filter when lukewarm. Drink a glass twice daily for ten days.

A treatment for fibromes could last about two to three months, depending on the patient's age.

\section{Study setting}

Cameroon is a bridge between Central Africa and West Africa, humid Africa and dry sahelian Africa, French speaking and English speaking Africa ( French and English are official languages). The country is open to the Gulf of Guinea in his south-west border. Lake Chad is at the extreme -North border. A country of 475.442 square kilometers, Cameroon is borded in the west by Nigeria, on the east by Chad and the Central African Republic, and on the south by Congo, Gabon, and Equatorial Guinea. 
The Bamoun are a Bantu people living in the west Region of Cameroon. They number more than half a million. They have a rich cultural Heritage, including famous traditional Healers. Sultan Njoya wrote a book on Bamoun traditional medicine. Important Bamoun towns are Foumban, Foumbot, Koutaba, Massangam, Magba, Malantouen. Among important villages are Mahoua, Manki 1 and Manki 2, where the plant Beilshmiedia anacardioides was collected.

\subsection{Generalities on Beilschmiedia anacardioides}

B. anacardioides is found in Central Africa, especially in Cameroon, Tchad and Gabon. In Cameroon, this species is found in the Adamaoua and the West Region (Eyog et al., 2006; Fouilloy, 1974). It is synonymous with B. ngriki and B. Jacques-felixii and it is commonly named ntseum (in Bamoun language) in the Noun subdivision of the West region of Cameroon (Eyog et al., 2006; Fouilloy, 1974; Tchouala, 2001).

\subsection{Uses of Beilschmiedia species in traditional medicine}

B. anacardioides stem bark is used in the Noun sub-division of the West Region of Cameroon to treat uterine tumours, rubella, rheumatisms, bacterial and fungal infections (Tchoula, 2001). Seeds are used as spices (Eyog et al., 2006). B. lancilimba is used in the same region to cure skin bacterial infections (Tchouala, 2001). B. manii is used to treat dysentery and headache. It is also used as an appetite stimulant (Iwu, 1993).

\section{Phytochemistry of plant constituents of Beilshmiedia species}

A review of the literature revealed that no phytochemial studies have been carried out on Beilshmiedia anacardioides prior to the initiation of our study. The various phytochemical and pharmacological studies performed and reported in the literature on the beilshmiedia genus are discussed below.

\subsection{Alkaloids isolated from the Beilschmiedia genus}

Very few alkaloids have been isolated from the Beilschmiedia genus.

\section{Structure and name}<smiles>COc1cc2c(cc1OC)Oc1ccc(cc1)C[C@H]1c3c(cc(OC)c(OC)c3Oc3ccc(cc3OC)C2)CCN1C</smiles>

Source and references

Wood of B. madang

(Kitagawa et al., 1993)

9: Dehatrine 
<smiles>COC1=C(O)C2=C3c4cc(OC)c(O)cc4CC3NCCC2=C1</smiles>

Stem bark of B. elliptica (Clezy et al., 1966)

10: Laurelliptine<smiles>COc1ccc(C(=O)c2ncc(C)c3cc(OC)c(OC)cc23)cc1</smiles>

Leaves of B. Brevipes

(Pudjiastuti et al.,2010)

11: (6,7-Diméthoxy-4-methylisoquinolinyl)-(4'methoxyphenyl)-methanone

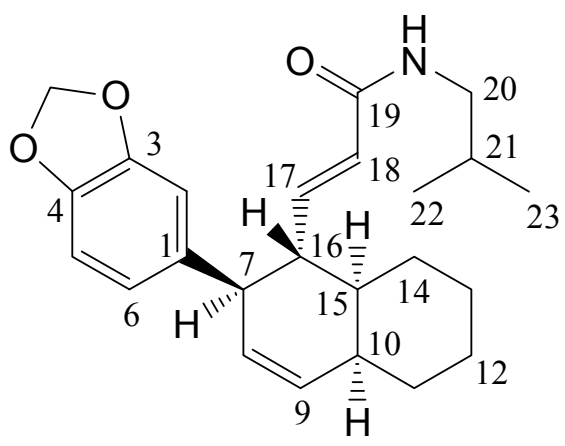

Stem bark of B. Obscura ( Lenta et al.,2011)

12: Obscurine

Table 1. Structure of some alkaloids isolated from the Beilschmiedia genus 
Pharmacological importance of alkaloids isolated from the Beilschmiedia genus

A bisbenzylisoquinoline alkaloid dehatrine (9) isolated from the wood of B. madang, exhibited potent inhibitory activity ( $\mathrm{IC}_{50}$ value of $0.017 \mu \mathrm{M}$ ) against the proliferation of the malaria pathogen P. falciparum (Kitagawa et al., 1993). Paulo and coworkers (1992) demonstrated the antimicrobial properties of laurelliptine (10).

\subsection{Phenolic and phenolic derived compounds}

\subsubsection{Lignans and neolignans}

Lignans and neolignans and flavonoids are the main phenolic compounds encountered in the Beilschmiedia genus.

\section{Structure and name}<smiles>COc1cc([C@H]2O[C@@H](c3cc(OC)c(OC)c(OC)c3)[C@H](C)[C@@H]2C)cc(OC)c1OC</smiles>

\section{Source and references}

Stem of B. tsangii

(Chen et al., 2006)

13: Beilschmin A<smiles>COc1cc([C@H]2O[C@@H](c3cc(OC)c(OC)c(OC)c3)[C@H](C)[C@@H]2C)cc(OC)c1OC</smiles>

Stem of B. tsangii

(Chen et al., 2006)

14: Beilschmin B<smiles>COc1cc([C@@]23O[C@@H](c4cc(OC)c5c(c4)OCO5)[C@@H](C)[C@]2(C)O3)cc(OC)c1OC</smiles>

Leaves of $B$. tsangii

(Chen et al., 2007)

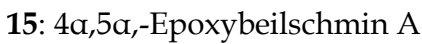


<smiles>COc1cc([C@@H]2O[C@@](O)(c3cc(OC)c(OC)c(OC)c3)[C@@H](C)[C@H]2C)cc(OC)c1OC</smiles>

16: 4a,5a,-Epoxybeilschmin B<smiles>COc1cc([C@@H]2OC(c3cc(OC)c4c(c3)OCO4)=C(C)[C@@H]2C)cc(OC)c1OC</smiles>

17: Beilschmin C<smiles>COc1cc([C@@H](OC(=O)c2cc(OC)c3c(c2)OCO3)[C@H](C)C(C)=O)cc(OC)c1OC</smiles>

18: Tsangin A<smiles>COc1cc([C@@H](OC(=O)c2cc(OC)c3c(c2)OCO3)[C@H](C)C(C)=O)cc(OC)c1OC</smiles>

19: Tsangin $B$
Stem of B. tsangii

(Chen et al., 2006)

Stem of $B$. tsangii

(Chen et al., 2006)

Stem of B. tsangii

(Chen et al., 2006)

Stem of B. tsangii

(Chen et al., 2006) 


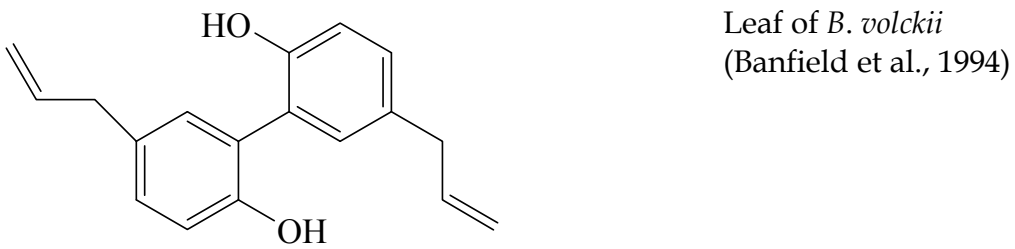

20: Magnolol

Table 2. Structure of some lignans and neolignans isolated from Beilschmiedia genus

Pharmacological importance of lignans and neolignans isolated from the Beilschmiedia genus

Tetrahydrofuran-type lignans beilschmin A (13) and B (14), dihydrofuran-type lignan beilschmin C (17) together with tsangin A (18) and B (19) were found cytotoxic (IC 50 value below $4 \mu \mathrm{g} / \mathrm{mL}$ ) in P-388 and/or HT-29 cell lines in vitro (Chen et al., 2006). In addition, beilschmin A (13) and B (14) exhibited potent antitubercular activity (MIC values of 2.5 and $7.5 \mu \mathrm{g} / \mathrm{mL}$, respectively) against Mycobacterium tuberculosis 90-221387 in vitro (Chen et al., 2007). A neolignan, magnolol (20) displayed wide biological properties, mainly cytotoxic ( $\mathrm{Li}$ et al., 2007), antidepressant (Li et al., 2007), antimicrobial (Park et al., 2004) and antiinflammatory (Lee et al., 2005).

\subsubsection{Some flavonoids isolated from Beilschmiedia genus}

\section{Pharmacological importance of flavonoids isolated from the Beilschmiedia genus}

Lenta and coworkers (2009), evaluated the antibacterial activities of the extract and flavonoids isolated from the stem of B. zenkeri, in vitro against three strains of microbes, pseudomonas agarici, Bacillus subtilis, and streptococus minor. Their activities were moderate compare to reference drugs ampicillin and gentamicin. (2S,4R)-5,6,7-trimethoxyflavan-4-ol (22a) exhibited the best potency against S. minor $\left(\mathrm{IC}_{50}\right.$ of $\left.197.5 \mu \mathrm{M}\right)$ (Lenta et al., 2009).

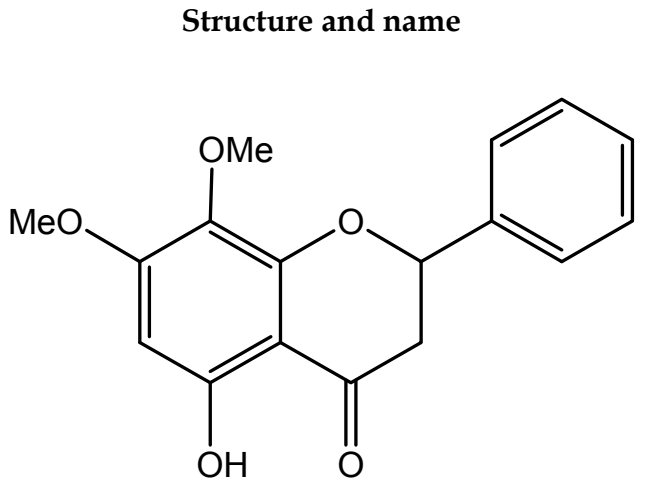

\section{Source and references}

Stem of $B$. zenkeri (Lenta et al., 2009)

21: 5-Hydroxy-7,8-dimethoxyflavanone 
<smiles>[R]OC1CC(c2ccccc2)Oc2cc(OC)c(OC)c(OC)c21</smiles>

22a: $\mathrm{R}=\mathrm{H}$ : (2S,4R)-5,6,7-trimethoxyflavan-4-ol 22b: $\mathrm{R}=\mathrm{CH} 3:(2 \mathrm{~S}, 4 \mathrm{R})-4,5,6,7$-trimethoxyflavan<smiles>[R]Oc1cc2c(c(OC)c1OC)C(OC1CC(c3ccccc3)Oc3cc(OC)c(OC)c(OC)c31)CC(c1ccccc1)O2</smiles>

Stem of B. zenkeri (Lenta et al., 2009)

Stem of B. zenkeri (Lenta et al., 2009)

23a: $\mathrm{R}=\mathrm{CH} 3$ : Beilschmieflavonoid $\mathrm{A}$

23b: $\mathrm{R}=\mathrm{H}$ : Beilschmieflavonoid B

Table 3. Structure of flavonoids isolated from the Beilschmiedia genus

\subsubsection{Other phenolic and phenolic derived compounds from the Beilschmiedia genus and their pharmacological importance}

Vanillin (21a) and 4-hydroxybenzaldehyde (24b) were isolated from Beilschmiedia tsangii (Chen et al., 2006). Both compounds were reported to exhibit analgesic, anti-inflammatory and antifungal activities (Lee et al., 2005; Lee et al., 2006; Fitzgerald et al., 2005). 


\section{Structure and name}<smiles>COc1cc(C=O)ccc1O</smiles>

\section{Source and references}

Stem of $B$. tsangii

(Chen et al., 2006)

24a: Vanillin<smiles>O=Cc1ccc(O)cc1</smiles>

Stem of $B$. tsangii

(Chen et al., 2006)

Bark of B. oligandra

(Banfield et al., 1994)

Root of B. erytrhophloia (Yang et al., 2008)

Root of B. erytrhophloia (Yang et al., 2008)<smiles>COc1ccc2c(c1)C=C[C@](C)(CC/C=C(\C)CCC=C(C)[O])O2</smiles>

25c: 3,4-Dehydrooligandrol methyl ether<smiles>COc1cc(C)c(O)c(CC=C(C)CCC=C(C)CCC=C(C)[Tl])c1</smiles>

Root of B. erytrhophloia (Yang et al., 2008)

26: Farnesylol

Table 4. Structure of other phenolic and phenolic derived compounds isolated from the Beilschmiedia genus 


\subsection{Endiandric acids}

Endiandric acids are a rare class of secondary tetracyclic metabolites generally encountered in Beilschmiedia and Endiandra species of the Lauraceae family. Endiandric acids are products of electrocyclic cyclization of naturally occurring polyketides (Bandanarayake et al., 1980).

\subsubsection{Some endiandric acids previously isolated}

\section{Pharmacological importance of the endiandric acids}

Very few pharmacological studies have been done in this class of metabolites. Endiandric acid $H(41)$ is used for the manufacture of medication, in particular for the treatment of asthmatic disorders or concomitant inflammatory symptoms of asthma (Eder et al., 2004).

Erytrophloin C (34) exhibited antitubercular activity (MIC value of $50 \mu \mathrm{g} / \mathrm{mL}$ ) against Mycobacterium tuberculosis H37Rv in vitro (Yang et al., 2009).

Structure and name

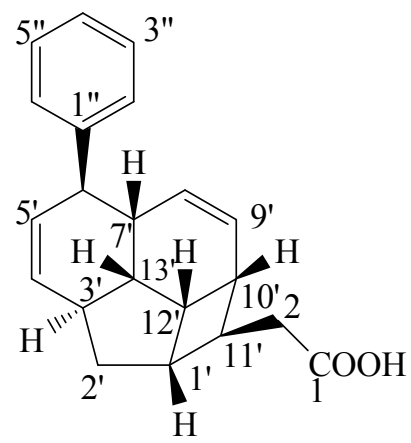

\section{Source and references}

Leaves of Endiandra entrorsa and Endiandra oligandra (Bandaranayake et al., 1981) Bark of B. oligandra (Banfield et al., 1994)

27: Endiandric acid A

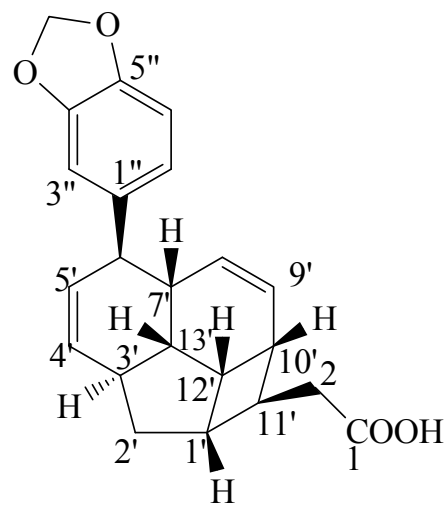

Leaves of Endiandra entrorsa (Banfield et al., 1994) and Stem bark of B. manii (Mpetga, 2005)

28: Methylenedioxyendiandric acid A 


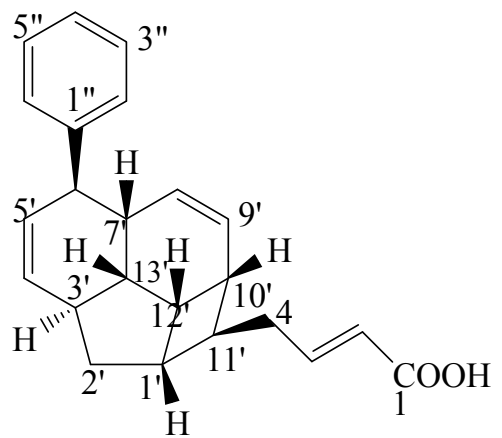

Leaves of Endiandra entrorsa

(Bandaranayake et al., 1982)

Barks and leaves of

Endiandra jonesii

(Banfield et al., 1994)

29: Endiandric acid B

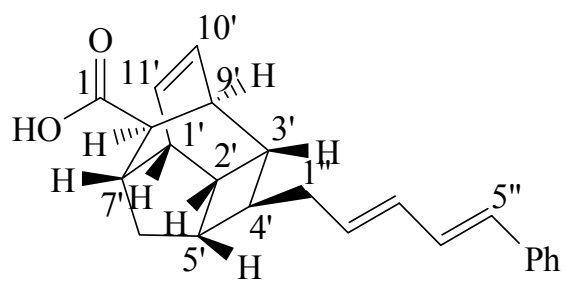

Leaves of Endiandra entrorsa

(Bandaranayake et al., 1982)

Bark and leaves of

Endiandra jonesii

(Banfield et al., 1994)

30: Endiandric acid C

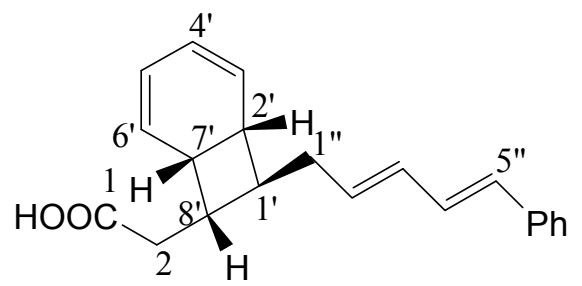

Leaves of Endiandra entrorsa

(Banfield et al., 1983)

Root of B. erytrhophloia

(Yang et al., 2009)

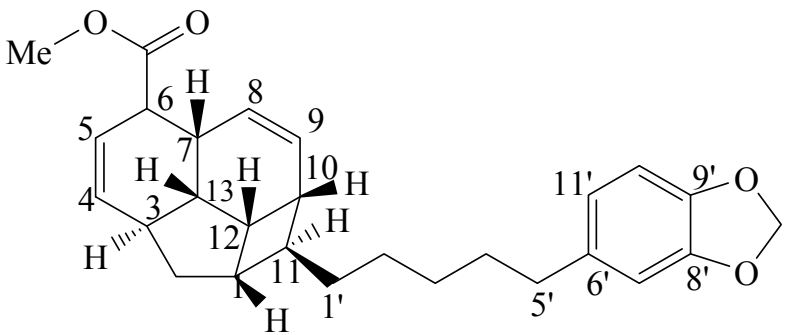

32: Erytrophloin A 


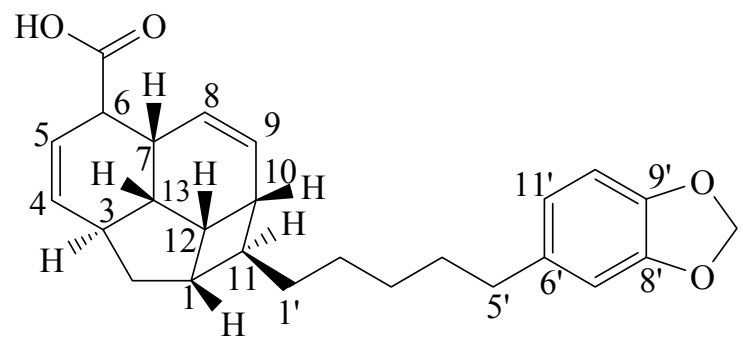

33: Erytrophloin F

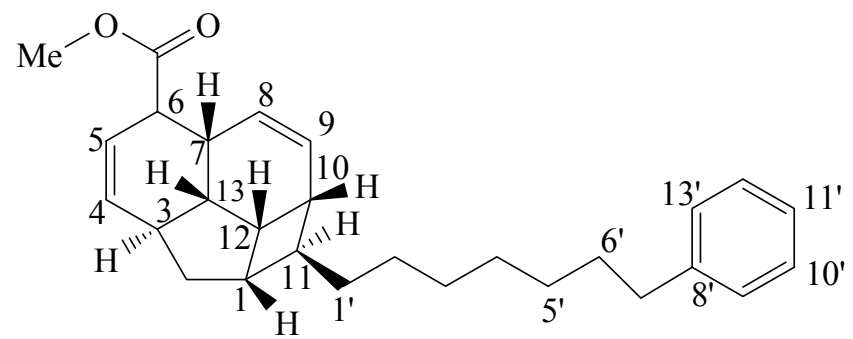

34: Erytrophloin C

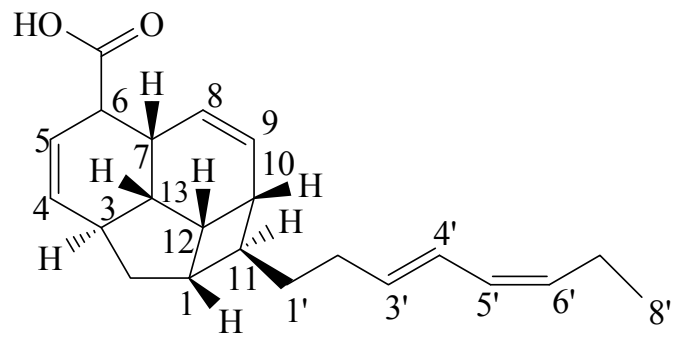

35: Erytrophloin E

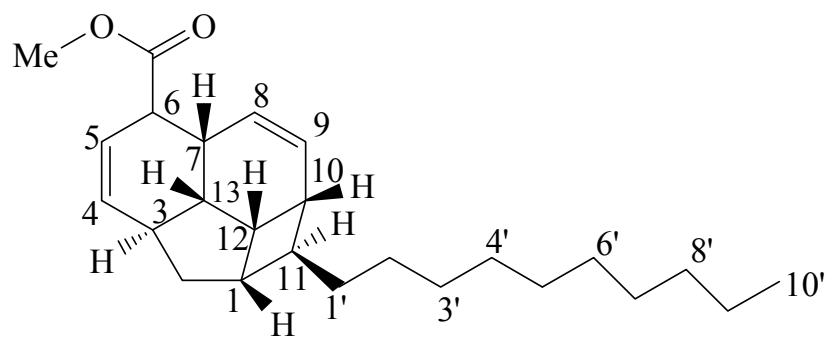

36: Erytrophloin B
Root of B. erytrhophloia

(Yang et al., 2009)

Root of B. erytrhophloia

(Yang et al., 2009)

Root of B. erytrhophloia

(Yang et al., 2009)

Root of B. erytrhophloia

(Yang et al., 2009) 


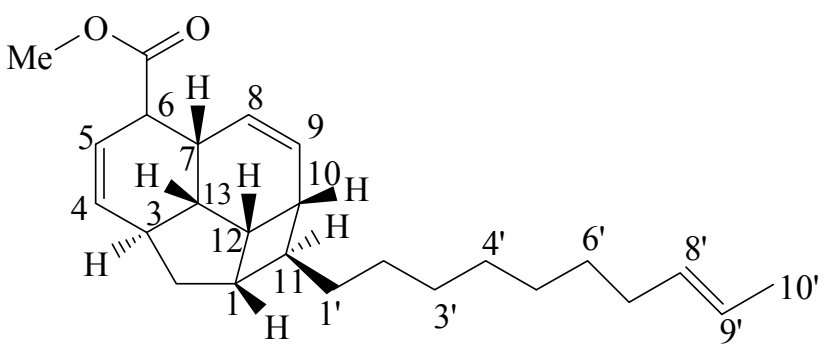

37: Erytrophloin D

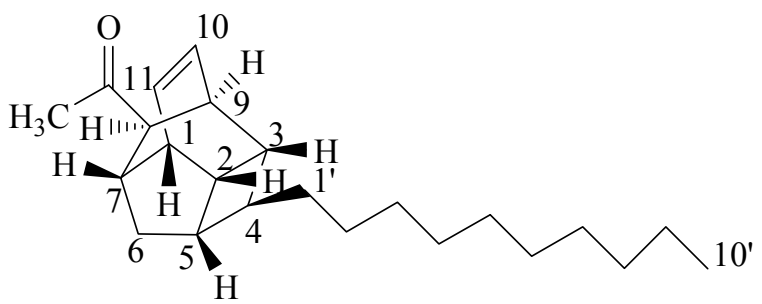

38: Beilcyclone

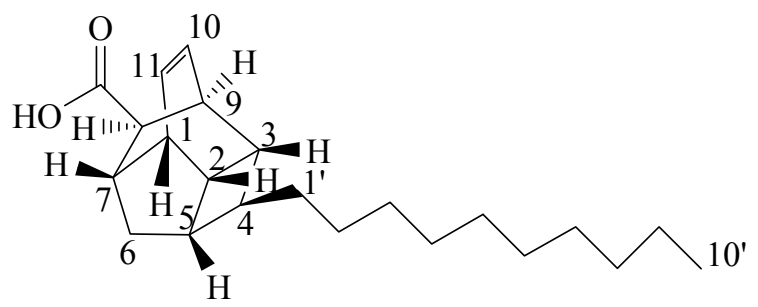

39: Endiandric acid J

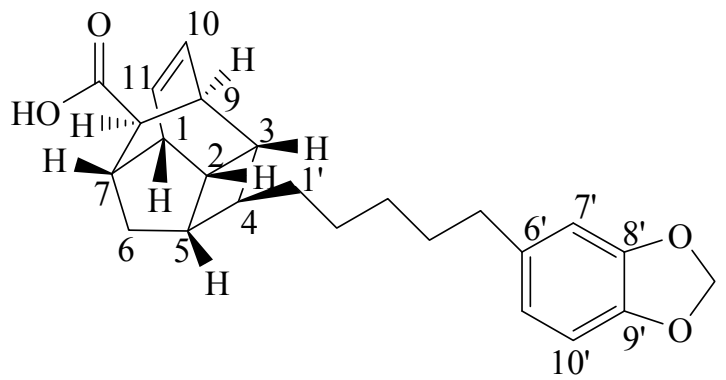

40: Endiandric acid I
Root of B. erytrhophloia

(Yang et al., 2009)

Root of B. erytrhophloia

(Yang et al., 2009)

Root of B. erytrhophloia

(Yang et al., 2008)

Root of B. erytrhophloia

(Yang et al., 2008) 


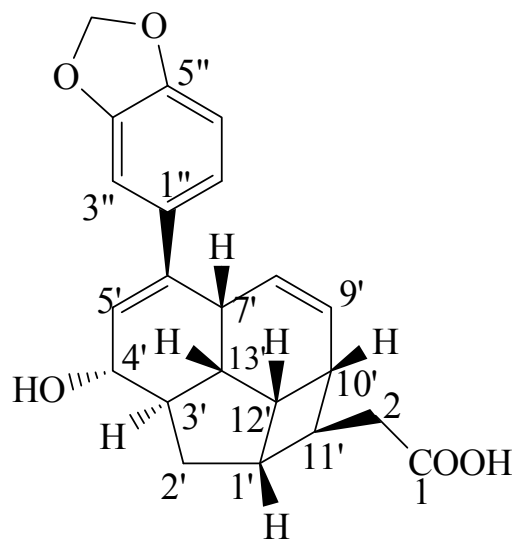

Stem of B. fulva (Eder et al., 2004)

41: Endiandric acid $\mathrm{H}$

Table 5. Structure of some endiandric acids previously isolated

\section{Results of our own studies}

We have initiated a systematic phytochemical investigation of the extracts of Beilshmiedia anacardioides and have so far obtained the following results which have led to three publications in renowned scientific journals (Chouna et al.,2009; 2010; 2011).

Air-dried and ground stem bark of $B$. anacardioides was extracted successively at room temperature with $\mathrm{MeOH}$. The methanol extract was re-extracted in turn with $\mathrm{CH}_{2} \mathrm{Cl}_{2}$ and EtOAc. These extracts were concentrated to dryness under reduced pressure.

The $\mathrm{CH}_{2} \mathrm{Cl}_{2}$ extract was submitted to repeated column chromatography on silica gel, yielding beilschmiedic acids A (1), B (2) and C (3) and the known $\beta$-sitosterol (Chouna et al.,2009) .

Further Successive purifications by column chromatography over silica gel and preparative TLC afforded three new endiandric acid derivatives: beilschmiedic acids $\mathrm{D}(4)$ and $\mathrm{E}(5)$, and Beilshmiedin (8) (Chouna et al.,2010), together with the known compounds bisabolene (Mossa et al 1992; Barrero et al. 1990), and tricosanoic acid (Erdemoglu et al., 2008).

The ethyl acetate soluble part of the $\mathrm{MeOH}$ extract of the stem bark of $B$. anacardioides was fractionated by column chromatography over silica gel. Successive purifications by column chromatography and preparative TLC afforded two new endiandric acid derivatives: beilschmiedic acids $F(6)$ and $G(7)$ Chouna et al.,2011, along with the known constituents beilschmiedic acid $\mathrm{A}(\mathbf{1})$, beilschmiedic acid C(3) [6] and sitosterol-3-O- $\beta$-D-glucopyranoside (Chouna et al.,2011). 

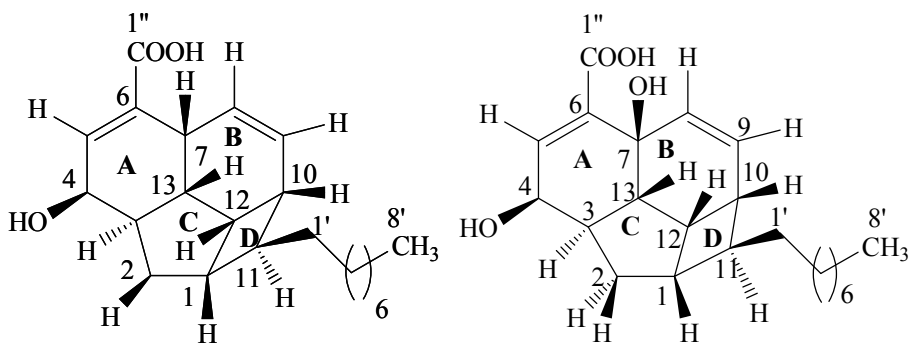

Beilshmiedic acid A ( 1) Beilshmiedic acid B ( 2)
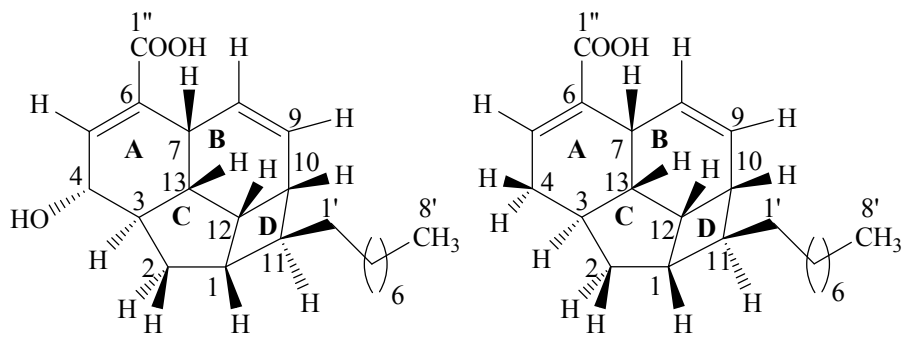

Beilshmiedic acid C ( 3) Beilshmiedic acid D ( 4)
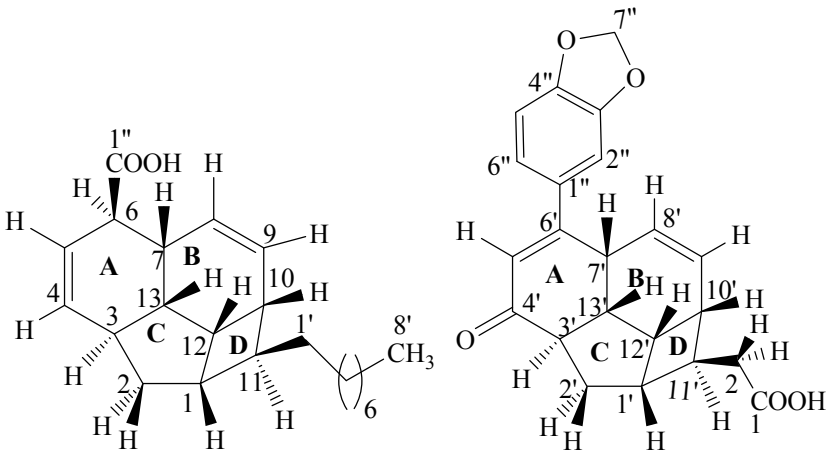

Beilshmiedic acid E ( 5) Beilshmiedic acid F ( 6)
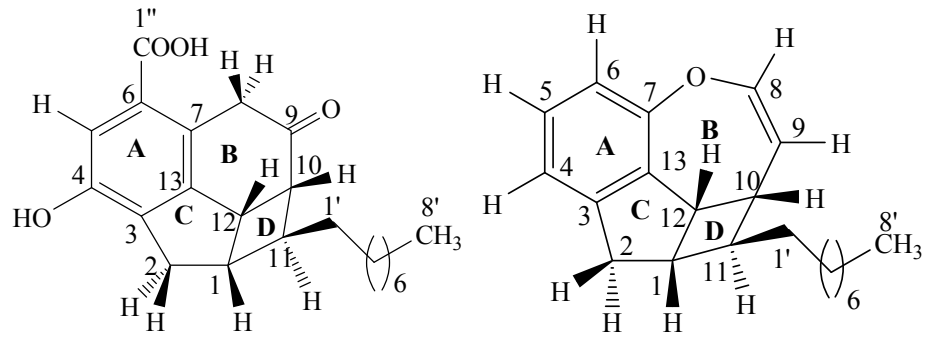

Beilshmiedic acid G ( 7) Beilshmiedin (8)

Scheme 1. endiandric acid derivatives from Beilshmiedia anacardioides. 


\section{Biological activity and the significance of some compounds}

Our preliminary antibacterial studies on the new endiandric acid derivatives have yielded chemical entities that have been shown to possess significant activities (Chouna et al., 2009) .

\section{Antibacterial assay on some compounds isolated from B.anacardioides}

Compounds 1-8 were tested in vitro for their antibacterial activity against Bacillus subtilis, Streptococcus ferus, Streptococcus minor, Micrococcus luteus, Escherichia coli, and Pseudomonas agarici, using the dilution technique.

The ZI (Table 1) and MIC (Table 2) obtained for these compounds indicated that they possessed strong to weak antibacterial activity against gram positive bacteria.

Beilshmiedic acid C (3) demonstrated the best potency against B. subtilis and M. luteus, compared to the reference drug ampicillin. The MIC values (Table 2) of Beilshmiedic acids $B(2), C(3)$ and $G(7)$, against B. subtilis and Beilshmiedic acid C (3) against M. luteus were found to be greater than that of standard drug ampicillin, indicating that this series of compounds might be possible candidates as antibacterial drugs.

None of the tested compounds was active against Gram negative P. palida and E. Coli. Therefore, they might be well tolerated as antibiotics even for long term treatments.

\begin{tabular}{|c|c|c|c|c|c|c|c|}
\hline Compound tested & B. subtilis & M. luteus & S. faecalis & S. minor & S. ferus & P. palida & E. coli \\
\hline 1 & 15 & 12 & 14 & n.t. & n.t. & - & - \\
\hline 2 & 16 & 15 & 15 & n.t. & n.t. & - & - \\
\hline 3 & 13 & 30 & 18 & n.t. & n.t. & - & - \\
\hline 4 & 10 & n.t. & n.t. & 10 & - & - & - \\
\hline 5 & 12 & n.t. & n.t. & - & 12 & - & - \\
\hline 6 & 10 & n.t. & n.t. & - & - & - & - \\
\hline 7 & 20 & 15 & 16 & - & - & - & - \\
\hline 8 & 10 & n.t. & n.t. & - & - & - & - \\
\hline Ampicillin & 29 & 26 & 25 & 22 & 23 & - & - \\
\hline
\end{tabular}

(-) inactive, n.t. (not tested)

Table 6. Antibacterial activity (Zone of inhibition of compounds in $\mathrm{mm}$ ) of compounds 1-8 $(500 \mu \mathrm{g} / \mathrm{mL})$ against B. Subtilis, M. luteus, S. faecalis, S. minor, S. ferus, P. palida and E. Coli. 


\begin{tabular}{llllll}
\hline Compound tested & B. subtilis & M. luteus & S. faecalis & S. minor & S. ferus \\
\hline $\mathbf{1}$ & 181.60 & 173.60 & 363.30 & n.t. & n.t. \\
$\mathbf{2}$ & 11.30 & 347.20 & 45.30 & n.t. & n.t. \\
$\mathbf{3}$ & 5.60 & $<0.70$ & 22.70 & n.t. & n.t. \\
$\mathbf{4}$ & 381.00 & n.t. & n.t. & 190.50 & - \\
$\mathbf{5}$ & 381.00 & n.t. & n.t. & 190.50 & - \\
$\mathbf{6}$ & 343.40 & n.t. & n.t. & - & - \\
$\mathbf{7}$ & 87.78 & 10.95 & 87.78 & - & - \\
$\mathbf{8}$ & 422.20 & n.t. & n.t. & - & - \\
Ampicillin & 89.5 & 1.95 & 3.9 & 1.05 & 5.25 \\
\hline
\end{tabular}

(-) inactive, n.t. (not tested)

Table 7. Antibacterial activity ( MIC in $\mu \mathrm{M}$ ) of compounds 1-8 against B. Subtilis, M. luteus, $S$. faecalis, S. minor, S. ferus, P. palida and E. coli.

Beilshmiedic acid C (3) was more active than Beilshmiedic acid D (4). The enhanced activity may be due to the additional hydroxyl group at C-4 position in Beilshmiedic acid C (3) . Beilshmiedic acid $\mathrm{B}(2)$ which possesses one hydroxyl group more than Beilshmiedic acid A (1) and Beilshmiedic acid C (3) was less active. Beilshmiedic acid A (1) was more active than Beilshmiedic acid C (3) . They are epimers at C-4 position; the modification of the configuration at this position influences significantly the activity.

Based on the skeletal features, it is difficult at this stage to define the contribution of the different functional groups with respect to the activity. The mechanism of action of this class of metabolites on these strains is not yet known. Further investigations will help to establish the mode of action of this particular skeleton. These interesting results highlight the potency of this rare class of metabolites that might be investigated for the search of new antibacterial drugs.

\section{Conclusion}

In our hypothesis we proposed that phytochemists looking for novel bioactive natural products should investigate the medicinal plants whose therapeutic efficiency has been established through clinical research on African medicine.

We suggested that Natural products from Beilshmiedia anacardioides may play a role in treating genital infections due to B-subtilis and M. luteus, and rheumatisms due Streptococcus ferus and S. minor. The biological activities of some of the constituents isolated in our studies, Beilshmiedic acid C presented above, more than lend support to this suggestion.

It is certain that as more and more data become available from the phytochemical and biological analysis of the constituents of therapeutic efficient medicinal plants selected after 
clinical research, the role of these plants in the treatment of diseases will become more defined. Thus African Traditional medicine will gain universal status.

\section{Acknowledgments}

Financial support for this survey from the Alango Foundation (Centre de Phytomédecine Africaine ) at Dschang / Cameroon is gratefully acknowledged.

\section{References}

Banfield, J.E.; Black, D.S.C; Fallon, G.D.; Gatehouse B.M.: Constituents of Endiandra species.V. 2-[3',5'-Dioxo-4'-phenyl-10'-\{(E,E)-5' -phenyl-penta-2", $4^{\prime \prime}$-dien-1"'-yl $\}$ $2^{\prime}, 4^{\prime}, 6^{\prime}$-triazatetracyclo[5,4,2,02,6,08,11] tridec $12^{\prime}$-en-9'-yl]-acetic acid derived from Endiandra introrsa (Lauraceae). Aust. J. Chem.1983, 36, 627-632.

Banfield J.E.; Black D.C.; Collins D.J.; Hyland B.P.M.; Lee J.J., Pranowo R.S. Constituents of some species of Beilschmiedia and Endiandra (Lauraceae): New Endiandric acid and benzopyran derivatives isolated from B. oligandra. Aust. J. Chem. 1994, 47, 587-607.

Bandaranayake, W.M.; Banfield, J.E.; Black, D.S.C.; Fallon G.D.; Gatehouse, B.M.: Constituents of Endiandra species. III. 4-[(E,E)-5'-Phenylpenta-2',4'-dien-1'-yl]tetracyclo[5,4,0,02,5,03,9] undec-10-ene-8-carboxylic acid from Endiandra introrsa (Lauraceae). Aust. J. Chem. 1982. 35, 567 - 579

Bandaranayake, W.M.; Banfield, JE; Black D.C.; Fallon, G.D.; Gatehouse B.M.: Constituents of Endiandra species. Endiandric acid, a novel carboxylic acid from Endiandra introrsa (Lauraceae) and a derived lactone. Aust. J. Chem. 1981, 34, 1655-1667.

Bandaranayake, W. M., Banfield, J. E., Black, D. C. Postulated electric reactions leading to endiandric acid and related natural products. J. Chem. Soc., Chem. Com. 1980, 13, 902-903.

Barrero A. F.; Alverez-Manzaneda, E.J.R.; Alverez-Manzaneda, R.R.: Bisabolene derivatives and other constituents from Achillea odorata. Phytochemistry 29, 3213-3216.

Chen, J.J.; Chou, E.T.; Duh, C.Y.;Yang, S.Z.;Chen, I.S.: New cytotoxic tatrahydrofuran- and dihydrofuran-type lignans from the stem of Beilschmiedia tsangii. Planta Medica. 2006. 72, 351-357.

Chen, J.J.; Chou, E.T.; Peng, C.F.; Chen, I.S.; Yang, S.Z.; Huang, H.Y.: Novel epoxyfuranoid lignans and antitubercular constituents from the leaves of Beilschmiedia tsangii. Planta Medica. 2007, 73, 567-571.

Clezy, P.S.; Gellert, E.; Lau, D.Y.; Nichol, A.W.: The alkaloids of Beilschmiedia elliptica. Aust. J. Chem.1966, 19, 135-142.

Chouna, J.R.; Nkeng-Efouet, P.A.; Lenta, B.N.; Devkota, K.P.; Neumann, B.; Stammler, H.G.; Kimbu, S.F.; Sewald, N. Antibacterial endiandric acid derivatives from Beilschmiedia anacardioides. Phytochemistry. 2009,70: 684-688.

Chouna, J. R.; Nkeng-Efouet, P. A.; Lenta, B. N.; Wansi, J. D.; Fon, K. S.; Sewald, N.. Endiandric acid derivatives from the stem bark of Beilschmiedia anacardioides. Phytochemistry Letters 3.2010, Pages 13-16.

Chouna,J. R.; Nkeng-Efouet, P. A. Lenta,B. N.; Wansi, J. D.; Stammlerf, B. N. H.; Fon, K. S.; Sewald, N.: Beilschmiedic Acids F and G, Further Endiandric Acid Derivatives from Beilschmiedia anacardioides. Helvetica Chimica Acta. 2011, 94, 1-7. 
Nurgün, E. E. A.; Akgöç M.; Simay, Ç.; Gökhan, B.: Comparison of the Seed Oils of Ferulago trachycarpa Boiss. From different localities with respect to Fatty Acids. Rec. Nat. Prod. 2008. 2:1, 13-18.

Eder, C.; Kogler, H.; Haag-Richter, S. 2004. Endiandric acid H and derivatives, procedure for its production and use of the same in the treatment of asthma. German patent 10235624.

Eyog Matig, O.; Ndoye, O.; Kengue, J.; Awano, A. Les fruitiers forestiers comestibles du Cameroun. 2006. Cotonou: IPGRI/SAFORGEN/IRAD/CIFOR.

Fouilloy, R. Flore du Cameroun (Lauracées, Myristicaées et Momimiacées). Paris, Muséum National d'Histoire Naturelle 18. 1974, p 8.

Fitzgerald, D.J.; Stratford, M.; Gasson, M.J.; Narbad, A. Structure function analysis of the vanillin molecule and its antifungal propertiesJ. Agric. Food Chem. 2005, 53, 17691775.

Harborne,J.B.; Mendez, J. Flavonoids of Beilsmiedia miersil. Phytochemisty. 1969, 8, 763-764.

Iwu, M.M. Handbook of African Medicinal Plants. CRC Press Inc, Boca Raton, Ann Arbour, London, Tokyo. 1993, p. 435.

Kitawaga, I.; Minagawa,K.; Zhang, R.S.; Hori, K.; Doi, M.; Ishida, T.; Kimura, M.; Uji, T.; Shibuya, H.; Dehatrine, H.: An antibacterial bisbenzylisoquinoline alkaloid from the Indonesian medicinal plant Beilsmiedia madang, isolated as a mixture of two rotational isomers. Chem. Pharm. Bull.1993, 41, 997- 999.

Lee, J.; Jung, E.; Park, J.; Yung, K.; Lee, S.; Hong, S.; Park, J.; Park, E.; Kim, J.; Park, S.; Park, D.: Anti-inflammatory effects of magnolol and honokiol are mediated through inhibition of the downstream pathway of MEJKK-1 in NF-kappaB activation signalling. Planta Medica.2005, 71, 338-343.

Lee, J. Y.; Jang, Y. W.; Moon, H.; Sim, S.; Kim, S Kang, H. S.: Anti-inflammatory action of phenolic compounds from Gastrodia elata root., Arch. Pharm. Res. 2006, 10, 849-859

Lenta, N.B.; Tantangmo, F.; Devkota, P.K.; Wansi, J.D.; Chouna, J.R.; Soh, F.R.C.; Neumann, B.; Stammler, H.G.; Tsamo, E.; Sewald, N.: Bioactives Constituents of the Stem Bark of Beilschmiedia zenkeri. Journal of Natural Products. 2009, 72, 2130-2134.

Lenta, B. N.; Chouna, J. R.; Nkeng-Efouet, P. A.; Fon, K. S.; Tsamo, E.; Sewald, N.: Obscurine, a New Cyclostachine Acid Derivative from Beilschmiedia obscura, 2011, Natural Product Communication. 2011,6:11,1591-1592.

Li, H. B.; Yi, X.; Gao, J. M.; Ying, X. X.; Guan, H. Q.; Li, J. C.: Magnoliol-induced H-460 cells death via autophagy but not apoptosis. Arch. Pharm. Res. 2007, 30, 1566-1574.

Moghaddam, M.F.; Farimani, M.M.; Salahvarzi, S.; Amin, F.: Chemical constituents of dichloromethane extract of cultivated Satureja khuzistanica. eCam . 2007, 4, 95-98.

Mpetga, S. D.J. Contribution à l'étude phytochimique d'une plante médicinale du Cameroun: Beilsmiedia mannii (Lauracée). Thèse de Doctorat en Chimie organique, Université de Dschang. 2005, p. 53.

Mossa, S.J.; Muhammad, I.; El-Feraly, S.F.; Hufford, D.C.; Mcphall, R.D.; Mc phall, T.A. Bisabolene and gualene sesquiterpenes from Policarta glutinosa, Phytochemistry. 1992, 31, 575-5780.

Pudjiastuti,P.; Mukhtar, M.R.; Hadi, A.H.A; Saidi,N.; Morita,H.; Litaudon, M.; Awang,K.: (6,7-Dimethoxy-4-methylisoquinolinyl)-(4' methoxyphenyl)-methanone, a New Benzylisoquinoline Alkaloid from Beilschmiedia brevipes. Molecules. 2010, 1-8. 
Paulo, M. Q.; Barbosa-Filho, J. M.; Lima, E.O.; Maria R. F.; Barbosa, R. C.; Kaplan, M.A. Antimicrobial activity of benzylisoquinoline alkaloids from Annona salzmanii. J. of Ethnopharmacol. 1992, 36, 39-41.

Park, J.; Lee, J.; Jung, E.; Park, Y.; Kim, K.; Park, B.; Yung, K.; Park, E.; Kim, J.; Park, D.: In vitro antibacterial and anti-inflammatory effects of honokiol and magnolol against Propionibacterium sp. Eur. J. Pharmacol. 2004, 12, 189-195.

Tchouala, J.M.: Inventaire ethnobotanique des plantes médicinales du Noun (OuestCameroun) utilisées pour soigner les infections fongiques et bactériennes. Mémoire de maitrise de Biologie Végétale, Université de Dschang. 2001, p. 33.

Yang, P.S.; Cheng, M.J.; Chen, I.J.; Chen, I.S.: Two new endiandric analogs, a new benzopyran and a new benzenoid from the root of Beilshmiedia erytroploia. Helv.Chim. Act. 2008, 91, 2130-2138. 


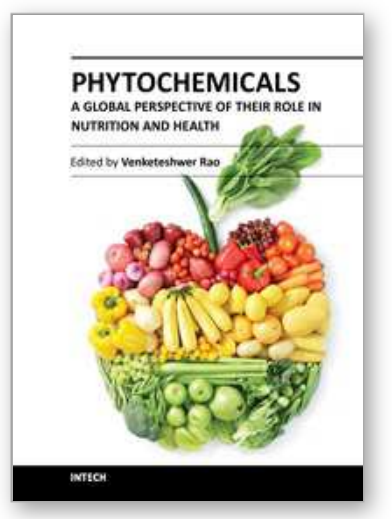

\author{
Phytochemicals - A Global Perspective of Their Role in Nutrition \\ and Health \\ Edited by Dr Venketeshwer Rao
}

ISBN 978-953-51-0296-0

Hard cover, 538 pages

Publisher InTech

Published online 21, March, 2012

Published in print edition March, 2012

Phytochemicals are biologically active compounds present in plants used for food and medicine. A great deal of interest has been generated recently in the isolation, characterization and biological activity of these phytochemicals. This book is in response to the need for more current and global scope of phytochemicals. It contains chapters written by internationally recognized authors. The topics covered in the book range from their occurrence, chemical and physical characteristics, analytical procedures, biological activity, safety and industrial applications. The book has been planned to meet the needs of the researchers, health professionals, government regulatory agencies and industries. This book will serve as a standard reference book in this important and fast growing area of phytochemicals, human nutrition and health.

\title{
How to reference
}

In order to correctly reference this scholarly work, feel free to copy and paste the following:

Nkeng-Efouet-Alango Pépin (2012). Phytochemicals from Beilschmiedia anacardioides and Their Biological Significance, Phytochemicals - A Global Perspective of Their Role in Nutrition and Health, Dr Venketeshwer Rao (Ed.), ISBN: 978-953-51-0296-0, InTech, Available from:

http://www.intechopen.com/books/phytochemicals-a-global-perspective-of-their-role-in-nutrition-andhealth/phytochemicals-from-beilshmiedia-anacardioides

\section{INTECH}

open science | open minds

\author{
InTech Europe \\ University Campus STeP Ri \\ Slavka Krautzeka 83/A \\ 51000 Rijeka, Croatia \\ Phone: +385 (51) 770447 \\ Fax: +385 (51) 686166 \\ www.intechopen.com
}

\author{
InTech China \\ Unit 405, Office Block, Hotel Equatorial Shanghai \\ No.65, Yan An Road (West), Shanghai, 200040, China \\ 中国上海市延安西路65号上海国际贵都大饭店办公楼 405 单元 \\ Phone: +86-21-62489820 \\ Fax: +86-21-62489821
}


(C) 2012 The Author(s). Licensee IntechOpen. This is an open access article distributed under the terms of the Creative Commons Attribution 3.0 License, which permits unrestricted use, distribution, and reproduction in any medium, provided the original work is properly cited. 